\title{
OPEC+ AS A NEW GOVERNOR IN GLOBAL ENERGY GOVERNANCE
}

\author{
Rafał Ulatowski ${ }^{1}$ \\ University of Warsaw
}

\begin{abstract}
:
This article tries to evaluate the roots of the OPEC+ agreement, how it operates, and its prospects for the future. It argues that OPEC+ is a new governor in the Global Energy Governance (GEG) "regime complex". It grew out of a convergence of the interests and capabilities of OPEC and non-OPEC exporters. The article shows that the emergence of OPEC+ is a consequence of over three decades of competition and occasional cooperation between exporters united in OPEC and those outside the organization. That cooperation was always a consequence of the price war and the demand of OPEC members for cooperation with non-OPEC exporters. Intensive consultations and three agreements on production cuts between both groups of countries in the years 2016-2019 made it possible to begin the institutionalization of cooperation among them. Cooperation within the OPEC+ agreement is nonformalized, based on government-to-government negotiations, and flexible. The signatories to the OPEC + agreement decided to avoid founding any formal IGO, and OPEC + continues to exist as a summit process.
\end{abstract}

Keywords: OPEC, Global Energy Governance, crude oil, Saudi Arabia, Russia, international cooperation

Título en Castellano: OPEP+ como nuevo regulador en la Gobernanza Global de la Energía

\section{Resumen:}

Este artículo trata de evaluar los orígenes del acuerdo OPEP+, cómo funciona y sus perspectivas de futuro. Argumenta que la OPEP+ es un nuevo regulador en el "complejo régimen" de LA Gobernanza Global de la Energía. Surgió de una convergencia de los intereses y capacidades de la OPEP y de los exportadores no pertenecientes a la OPEP. El artículo muestra que el surgimiento de la OPEP+ es una consecuencia de más de tres décadas de competencia y cooperación ocasional entre los exportadores reunidos en la OPEP y los que están fuera de la organización. Esta cooperación siempre fue consecuencia de la guerra de precios y de la demanda de cooperación con los exportadores no pertenecientes a la OPEP. Las intensas consultas y tres acuerdos sobre recortes de producción entre ambos grupos de países en los años 2016-2019 hicieron posible iniciar la institucionalización de la cooperación entre ellos. La cooperación en el marco del acuerdo OPEP+ no está formalizada, basada en negociaciones entre gobiernos y flexible. Los signatarios del acuerdo OPEP + decidieron evitar fundar ninguna OVI formal, y la OPEP + sigue existiendo como un proceso de cumbre.

Palabras Clave: OPEC, gobernanza global de la energía, petróleo crudo, Arabia Saudita, Rusia, cooperación internacional.

Copyright (C) UNISCI, 2019.

Las opiniones expresadas en estos artículos son propias de sus autores, y no reflejan necesariamente la opinión de UNISCI. The views expressed in these articles are those of the authors, and do not necessarily reflect the views of UNISCI.

\footnotetext{
${ }^{1}$ Rafał Ulatowski is Assistant Professor at the Faculty of Political Science and International Studies, University of Warsaw.

E-mail:<r.ulatowski@uw.edu.pl>

DOI: http://dx.doi.org/10.31439/UNISCI-94
} 


\section{Introduction}

Global energy governance (GEG), defined as "international collective efforts undertaken to manage and distribute energy resources and provide energy services" ${ }^{2}$, has emerged as one of the most important issues in international relations in the early $21^{\text {st }}$ century ${ }^{3}$.

The impulse for the discussion on GEG was given by world leaders at the 2005 G8 summit in Gleneagles. The current studies concentrate on the "rules, norms, markets and institutions" " Differently than in many other areas, there is no single organization or institution responsible for $\mathrm{GEG}^{5}$. Global energy is governed by so-called 'governors' forming a "regime complex" . The number of governors identified ranges from $\operatorname{six}^{7}$ to $128^{8}$, and is still growing. The reason for the differentiation in the number of governors indicated in different studies is the elusiveness of the concept. First, some authors concentrate solely on governmental organizations and the summit process, while others also include non-governmental organizations (NGOs), financial institutions, public-private partnerships, transnational networks of advocacy, global policy network, and quasi-regulatory private bodies ${ }^{9}$. Second, some authors concentrate solely on oil- and gas-related organizations ${ }^{10}$, whereas others also include organizations dealing with atomic energy, renewables, low-carbon technologies, etc ${ }^{11}$.

Despite the proliferation of organizations engaged in GEG, two have played a crucial role and capture the most interest. These are the Organization of Petroleum Exporting Countries (OPEC) and the International Energy Agency (IEA). For decades, OPEC has been the most important organization uniting oil exporters ${ }^{12}$, and has frequently been labelled as an oil cartel ${ }^{13}$.

${ }^{2}$ Florini, Ann and Sovacool, Benjamin K.: "Who governs energy? The challenges facing global energy governance", Energy Policy, Vol. 37, n 12 (December 2009), pp. 5239-5248.

${ }^{3}$ Lesage, Dries; Van de Graaf, Thijs and Westphal, Kirsten (2010): Global Energy Governance in a Multipolar World, Abingdon, Ashgate.; Goldthau, Andreas and Witte, Jan Martin (eds.) (2010): Global Energy Governance. The new rules of the game, Washington, D.C., Brookings Press.; Van de Graaf, Thijs (2013): The Politics and Institutions of Global Energy Governance, Basingstoke, Palgrave Macmillan.; Van de Graaf, Thijs and Colgan, Jeff: "Global energy governance: A review and research agenda", Palgrave Communications, n 2 (January 2016), pp. 1-12.

${ }^{4}$ Van de Graaf, Thijs: "Organizational Interactions in Global Energy Governance”, in Biermann, Rafael and Koops, Joachim A. (eds.) (2016): Palgrave Handbook of Inter-Organizational Relations, Houndmills, Palgrave Macmillan, pp. 591-609.

${ }^{5}$ ElBaradei, Mohamed: "A global agency is needed for the energy crisis", Financial Times, 23 July 2008 , at https://www.ft.com/content/b3630dd0-58b5-11dd-a093-000077b07658.

${ }^{6}$ Raustiala, Kal and Victor, David G.: "The Regime Complex for Plant Genetic Resources", International Organization, Vol. 58, no 2 (April 2004), pp. 277-309.; Kirton, John: “The G8 and Global Energy Governance: Past Performance, St. Petersburg Opportunities". Paper Presented at a Conference on "The World Dimension of Russia's Energy Security, 21 April 2006, at

http://www.g8.utoronto.ca/scholar/kirton2006/kirton_energy_060623.pdf

${ }^{7}$ Kérébel Cécile - Keppler Jan Horst (2009): La gouvernance mondiale de l'énergie, Paris, IFRI.

${ }^{8}$ Sanderink, Lisa; Kristensen, Kristian; Widerberg, Oscar and Pattberg, Philipp: "Mapping the Institutional Architecture of Global Energy Governance”, IVM Institute for Environmental Studies, Report R-18/02 (2018), at https://www.researchgate.net/publication/327011883_Mapping_the_Institutional_Architecture_of_Global_Energ y_Governance

${ }_{9}^{9}$ Sovacool, Benjamin K. and Florini Ann: "Examining the complications of global energy governance", Journal of Energy \& Natural Resources Law, Vol. 30, nº 3 (2012), pp. 235-263.

${ }^{10}$ Kérébel and Keppler: op. cit.

${ }^{11}$ Sanderink; Kristensen; Widerberg and Pattberg: op.cit.

${ }^{12}$ Parra, Francisco (2004): Oil Politics: A Modern History of Petroleum, London, I.B.Tauris.

${ }^{13}$ Hnyilicza, Esteban and Pindyck, Robert S.: "Pricing policies for a two-part exhaustible resource cartel: The case of OPEC", European Economic Review, Vol. 8, no 2 (August 1976), pp. 139-154.; Pindyck, Robert S.: "Gains to Producers from the Cartelization of Exhaustible Resources", Review of Economics and Statistics, Vol. 60, No. 2 (April 1978), pp. 238-251.; Adelman, Morris A.: "The Clumsy Cartel”, The Energy Journal, Vol. 1, no 1 (January 1980), pp. 43-53.; Seymour, Ian (1980): OPEC. Instrument of Change, Basingstoke, Palgrave Macmillan.; Ikenberry, John G. (1988): Reasons of State: Oil Politics and the Capacities of American Government, Ithaca - 
It has also been seen as the first governor in the history of GEG. OPEC's creation by oil exporting countries ${ }^{14}$ and their success in managing the oil market in the 1970s was a reason for the development of other governors, including the IEA, in the following decades ${ }^{15}$. Rivalry among members of both organizations is a function of competition over control of the oil market. This competition has led to difficulties in developing cooperation between the IEA and OPEC, which was first mitigated by the creation of the International Energy Forum (IEF) in $1991^{16}$.

Current studies on GEG governors exhibit several limitations.

First, they postulate stronger cooperation between producer and consumer countries ${ }^{17}$, which may be praiseworthy, but in fact does not go beyond non-committal discussion.

Second, inter-organizational cooperation ${ }^{18}$ is strongly emphasized, though in reality organizations are instruments in the hands of the major powers. Much more attention should be paid to the relations that exist between and among states.

Third, in spite of the rapid development of renewables and improvements in energy efficiency, the demand for oil is unlikely to peak in the near future. The world will still be using oil for decades to come ${ }^{19}$, and control over oil reserves will remain both an instrument and a goal of state power.

To overcome some of these limitations, the case study of the OPEC+ agreement concluded in 2016 by OPEC and non-OPEC exporters is discussed. Although there is big interest in the media in the OPEC+ agreement, to date there has been no publication discussing it. This leaves a significant research gap in the study of GEG. The goal of this article is to evaluate the roots of the OPEC+ agreement, how it operates, and its prospects for the future. I argue that OPEC+ is a new governor in the GEG "regime complex", which should be characterized as a summit process. The summit process offers "a sort of 'halfway house' between formal IGOs and the normal practices of diplomacy between national governments". It has "no charter, fixed membership or secretariat, but offers a flexible way to address pressing multilateral problems." ${ }^{20}$. OPEC + grew out of a convergence of the interests and capabilities of OPEC and non-OPEC exporters.

The article contains four sections. Section 1 discusses the concept of 'governor' in GEG. Section 2 looks into the historical roots of the OPEC+ agreement. Section 3 analyses OPEC and non-OPEC cooperation in the period 2016-2019. Section 4 discusses the institutionalization of OPEC+.

\section{The concept of 'governor' in GEG}

Despite the proliferation of non-governmental organizations (NGOs) engaged in GEG, their importance has been exaggerated. Nor are they a new phenomenon ${ }^{21}$. The principal actors in

London, Cornell University Press.; Smith, James L.: "Inscrutable OPEC? Behavioral Tests of the Cartel Hypothesis", The Energy Journal, Vol. 26, no 1 (2005), pp. 51-83.

${ }^{14}$ Iran, Irak, Kuwait, Saudi Arabia and Venezuela.

${ }^{15}$ Van de Graaf, Thijs (2013): The Politics and Institutions of Global Energy Governance, op. cit., pp. 44-63.

${ }^{16}$ Van de Graaf: "Organizational Interactions in Global Energy Governance", op.cit., pp. 591-609.

${ }^{17}$ Fattouh, Bassam and van der Linde, Coby (2011): The International Energy Forum. Twenty years of producerconsumer dialogue in a changing world, Riyadh, IEF.

${ }^{18}$ Van de Graaf: "Organizational Interactions in Global Energy Governance", op.cit., pp. 591-609.

${ }^{19}$ IEA (2018): Oil 2018. Analysis and Forecasts to 2023, Paris, International Energy Agency.

${ }^{20}$ Sovacool and Florini: op. cit., p. 238.

${ }^{21}$ Green, Jessica F. and Colgan, Jeff: "Protecting Sovereignty, Protecting the Planet: State Delegation to International Organizations and Private Actors in Environmental Politics", Governance, Vol. 26, nº 3 (July 2013), pp. 473-497. 
GEG continue to be states. It is they that set and enforce the rules in $\mathrm{GEG}^{22}$. States behave egoistically, individualistically and competitively ${ }^{23}$. Traditionally, the energy sector has been a source of conflict in international relations, which is a reason for its weak institutionalization ${ }^{24}$.

Despite the conflictual character of the energy market, states have developed different forms of cooperation, with the creation of energy-oriented organizations being the most popular type of cooperation, though not the only one. There are several reasons for them to participate in energy-oriented organizations: 1) such an organization may facilitate the exchange of information between the governments of member states; 2) it can serve as a forum for presenting the intentions of the participating states; 3 ) it can be helpful in setting standards for national energy policies, lower transaction costs and improving the transparency of the energy market; 4) cooperation can help members of the organization to reduce volatility on the market ${ }^{25}$; 5) members of such an organization can have an impact on setting production quotas and pricing decisions; and 6) membership in an energy-oriented international organization and the coordinated use of energy resources may bring political benefits, providing leverage in foreign and security policy. Exceptions from participation in an energy-oriented organization tend to be politically motivated ${ }^{26}$. This explains why the number of OPEC members has grown, from five in 1960 to 14 today. The cases of three oil exporters that have never joined OPEC: Mexico $^{27}$, Norway ${ }^{28}$ and Russia ${ }^{29}$, confirm the crucial role of political factors in their choosing not to do so.

Jeffrey D. Wilson explains why, despite the potential benefits, "more robust cooperative mechanisms" have never been developed in the energy sector. He points out that all international organizations suffer to a certain degree from three types of challenges: 1) the membership issue, which limits the relevance of an organization, 2) the design issue, which limits the capability of an organization to go beyond discussion, and 3) the commitment issue, which does the same. Wilson identified limited membership as a key problem for OPEC, since there are substantial new sources of production in countries outside the organization ${ }^{30}$.

\footnotetext{
${ }^{22}$ Van de Graaf, Thijs and Zelli, Fariborz: "Actors, Institutions and Frames in Global Energy Politics", in Van de Graaf, Thijs; Sovacool, Benjamin K.; Ghosh, Arunabha; Kern, Florian and Klare, Michael T. (eds.) (2016): The Palgrave Handbook of the International Political Economy of Energy, Basingstoke, Palgrave Macmillan, pp. 4771.

${ }^{23}$ Waltz, Kenneth N. (1979): Theory of international politics, Long Grove, Waveland.; Grieco, Joseph M.: "Anarchy and the Limits of Cooperation: A Realist Critique of the Newest Liberal Institutionalism", International Organization, Vol. 42, no 3 (Summer 1988), pp. 485-507.

${ }^{24}$ Westphal, Kirsten: “Energy Policy between Multilateral Governance and Geopolitics: Whither Europe?", IPG, $\mathrm{n}^{\circ} 4$ (January 2006), pp. 58.

${ }^{25}$ Wilson, Jeffrey D.: "Multilateral Organizations and the Limits to International Energy Cooperation", New Political Economy, Vol. 20, no 1 (2015), pp. 87.

${ }^{26}$ Baccini, Leonardo; Lenzi Veronica and Thurner, Paul W.: "Global Energy Governance: Trade, Infrastructure, and the Diffusion of International Organizations", International Interactions. Empirical and Theoretical Research in International Relations, Vol. 39, $\mathrm{n}^{\circ} 2$ (2013), pp. 192-216.

${ }^{27}$ Cameron, Maxwell A. and Tomlin, Brian W. (2000): The Making of NAFTA. How the Deal Was Done, Ithaca London, Cornell University Press.; Grayson, George (1988): Oil and Mexican Foreign Policy, Pittsburgh, University of Pittsburgh Press, pp. 107-110.

${ }^{28}$ Mann, Yossi: "Saudi Arabia's Policy Toward non-OPEC Countries", Diplomacy \& Statecraft, Vol. 23, No. 2 (2012), pp. 385-386.; Claes, Dag H. (2001): The Politics of Oil-producer Cooperation, Boulder, Westview Press, pp. $297-352$.

${ }^{29}$ Elass, Jareer and Jaffe, Amy M.: "The History and Politics of Russia's Relations with OPEC", James A. Baker III Institute for Public Policy of Rice University, (2009), at https://scholarship.rice.edu/bitstream/handle/1911/91409/EF-pub-ElassJaffeRussiaOPEC050609.pdf?sequence=1\&isAllowed=y.; Mann: "Saudi Arabia's Policy Toward non-OPEC Countries, op. cit., p. 388.

${ }^{30}$ Wilson: op. cit., pp. 85-106.
} 
In her study on the vitality of international organizations, Julia Grey shows that they end up in one of three possible situations: first, they may die out, but this happens only rarely. Second, they may turn into a "zombie", meaning that they continue operating, but make no progress in respect of their mandate. The third possibility is that they develop and function effectively ${ }^{31}$. Jeff D. Colgan, Robert O. Keohane and Thijs Van de Graaf have further developed this idea, and have shown that international organizations change over time. They argue that OPEC members "reinvigorated the organization" in the late 1990s and began cooperating with nonmember exporters to face the challenge of the oil price collapse of $1998^{32}$.

Also, exporters outside OPEC have a long-term economic interest in cooperating. The aggregated growth in numerous non-OPEC countries can negatively affect price levels. They share the interest of OPEC producers in keeping prices high, especially taking into consideration their relatively high production costs. They are also vulnerable to reductions in revenues resulting from price drops. In the absence of the possibility of a free ride, all exporters - big and small, OPEC and non-OPEC members - have an interest in cooperating ${ }^{33}$.

In the event that non-cooperative behaviour leads to an oversupply of the market, a price war is the only mechanism that can force exporters to cooperation and relax overproduction. Due to its spare capacity, there is one country that can start a price war: Saudi Arabia ${ }^{34}$. The threat of a price war is only credible when supply exceeds demand ${ }^{35}$, whereas for a price war to be successful, one of two possible situations must exist. First, a fall of the oil price below the cost of production, or second, when the price of oil achieves a historically low level. The first situation was noted by Yossi Mann, who studied the relations between OPEC and Norway. He observed that cooperation between Norway and OPEC only takes place when oil prices are lower than the cost of production in Norway ${ }^{36}$. In a situation of the second type, exporters tend to cooperate when the price achieves a historically low level. The consequence is a drastic rise in budget deficit and possible default ${ }^{37}$.

Cooperation among oil exporters has not only economic but also political aims. As early as 1964, a distinguished economist wrote: "the world oil problem is political before it is economic" 38 . This has not changed. Jeff D. Colgan argues that we should look more at the political role of OPEC. His research shows that: "The idea of OPEC as a cartel is a "rational myth" that supports the organization's true principal function, which is to generate political

\footnotetext{
${ }^{31}$ Gray, Julia: "Life, Death, or Zombie? The Vitality of International Organizations", International Studies Quarterly, Vol. 62, nº 1 (March 2018), pp. 1-13.

${ }^{32}$ Colgan, Jeff D.; Keohane, Robert O. and Van de Graaf, Thijs: "Punctuated equilibrium in the energy regime complex", Review of International Organizations, Vol. 7, nº 2 (2012), pp. 135.

33 Mabro, Robert: "The Oil Price Crisis of 1998", OIES Working Paper, SP10 (1998), at https://www.oxfordenergy.org/wpcms/wp-content/uploads/2010/11/SP10-TheOilPriceCrisisof1998-RMabro-

1998.pdf.; Noreng, Øystein: "Friends or fellow travellers? The relationship of non-OPEC exporters with OPEC", The Journal of Energy and Development, Vol. 4, nº 2 (Spring 1979), pp. 313-335.

${ }^{34}$ Al-Naimi, Ali Ibrahim: “A Discussion with His Excellency Ali Ibrahim Al-Naimi”, Center for Strategic \& International Studies, 2 December 2016, at https://www.csis.org/events/discussion-his-excellency-ali-ibrahim-alnaimi

${ }^{35}$ Fattouh, Bassam: “An Anatomy of the Crude Oil Pricing System”, OIES Working Paper, WPM 40 (2011), at https://www.oxfordenergy.org/wpcms/wp-content/uploads/2011/03/WPM40-

AnAnatomyoftheCrudeOilPricingSystem-BassamFattouh-2011.pdf, p. 18.; Claes, Dag H. (2018a): The Politics of Oil: Controlling Resources, Governing Markets and Creating Political Conflicts, Cheltenham, Edward Elgar Publishing, p. 140.

${ }^{36}$ Mann, "Saudi Arabia's Policy Toward non-OPEC Countries”, op. cit., pp. 385-386.

${ }^{37}$ Kohl, Wilfrid L.: "OPEC behavior, 1998-2001", The Quarterly Review of Economics and Finance, Vol. 42, no 2 (June 2002), pp. 209-233.

38 Adelman, Morris A.: "Efficiency of Resource Use in Crude Petroleum", Southern Economic Journal, Vol. 31, no 2 (October 1964), pp. 114.
} 
benefits for its members. One benefit it generates is international prestige" 39 . OPEC's political role as an energy-orientated organization is more important than its economic role ${ }^{40}$. Saudi Arabia allows poorer members of the organisation to overproduce in exchange for acceptance of its political leadership in the organization ${ }^{41}$. The political aspects of the OPEC+ agreement should be also kept in mind.

\section{Historical roots of OPEC+ agreement}

In this section of the article, I concentrate on two historical cases of OPEC-non-OPEC negotiations conducted in order to manage the oil market. The first happened in the mid-1980s, and the second at the turn of the millennium.

Attempts by OPEC to coordinate production with non-OPEC suppliers go back to the early 1980s. At that time, OPEC was losing its market share at an accelerated pace. It fell from $51 \%$ in 1973 to $28 \%$ in $1985^{42}$. The rising market share of non-OPEC producers and the falling oil prices observed since 1982 made OPEC's relations with non-OPEC producers of key interest for OPEC officials and those ministers in OPEC member countries responsible for oil policy. Beginning in 1982, the goal was to convince the newly emerged producers to join the organization, or at least to develop a mechanism of cooperation on production ceilings and prices. In 1983, OPEC established contacts with Mexico, the Soviet Union, Egypt, China, and Great Britain ${ }^{43}$.

Morris A. Adelman indicated two problems OPEC faced for the first time in the early 1980s. The first was how to calculate output and price so as to maximize revenue. Price should not harm demand, and must always be corrected as global supply and demand change. Opinions differed widely as to the right price levels, and OPEC always set prices by trial and error. The second problem was how to divide sales among the OPEC members ${ }^{44}$. OPEC introduced a quota system which gave every member state the right to produce a certain amount of oil. Saudi Arabia decided to act as a swing producer, elastically raising and lowering production to keep prices stable. But as early as 1985 it had to admit that this policy had failed: even a huge reduction in Saudi production from 10.2 million b/d in 1980 to 3.6 million b/d in 1985 did not stop prices from falling. Saudi Arabia understood that it was unable to manage the market on its own. Since the mid-1980s, then, Saudi Arabia has expected cooperation not only from other OPEC member states, but also from exporters outside the organization. By seeking cooperation with non-OPEC producers, its members consoled each other with the thought that global demand for oil would go up, and in the long term, only OPEC's huge reserves would be able to satisfy it ${ }^{45}$. In the first half of 1986 Saudi Arabia adopted a netback pricing system, effectively flooding the market with its oil and provoking a price $\mathrm{crash}^{46}$. A price war began. Saudi Arabia

\footnotetext{
${ }^{39}$ Colgan, Jeff D.: "The Emperor Has No Clothes: The Limits of OPEC in the Global Oil Market", International Organization, Vol. 68, no 3 (Summer 2014), p. 599.

${ }^{40}$ Ibid., pp. 601.

${ }^{41}$ Blaydes, Lisa: "Rewarding Impatience: A Bargaining and Enforcement Model of OPEC", International Organization, Vol. 58, $\mathrm{n}^{\circ} 2$ (Spring 2004), pp. 213-237.; Claes, Dag H. (2018). Saudi Arabia and OPEC: Governing the World Energy Regime, Paper to be presented at the 59th Annual Convention International Studies Association.

${ }^{42}$ Fattouh: "An Anatomy of the Crude Oil Pricing System”, op. cit., p. 18.

${ }^{43}$ Shwadran, Benjamin: "Middle East Oil Developments 1983-84", in Shaked, Haim and Dishon, Daniel (eds.) (1986): Middle East Contemporary Survey, Boulder - San Francisco - London, Westview Press, pp. 265-279.

${ }^{44}$ Adelman, Morris A.: "The Real Oil Problem", Regulation, Vol. 27, no 1 (Spring 2004), pp. 16-21.

${ }^{45}$ Griffin, James M. and Neilson, William S.: "The 1985-86 oil price collapse and afterwards: what does game theory add?", Economic Inquiry, Vol. 32, no 4 (October 1994), pp. 543-561.; Luciani, Giacomo: "Saudi Arabia and the limits of signalling", OIES Forum, no 100 (2015), pp. 17.; Fattouh: "An Anatomy of the Crude Oil Pricing System", op. cit.

${ }^{46}$ Fattouh: "An Anatomy of the Crude Oil Pricing System", op. cit., p. 18-19.
} 
didn't want to leave the market to other producers anymore, and demanded a bigger market share for itself $^{47}$. Between November 1985 and March 1986, prices fall by 66\% ${ }^{48}$. In 1980, OPEC members earned 282.625 billion USD on petroleum exports; in 1986 that figure was only 76.64 billion USD ${ }^{49}$. The price war hit also non-OPEC exporters. The fall in oil income showed that the economic modernization financed by oil income had failed. OPEC and nonOPEC oil exporters suffered from a resource curse ${ }^{50}$. The oil price crash of the mid-1980s also had political implications, including that it contributed to the fall of the Soviet Union in $1991^{51}$.

After the price collapse of the mid-1980s, diplomatic exchanges between both groups of exporters continued. In January 1987, Saudi Arabia sent Hisham Nazer (the minister of petroleum and mineral resources of Saudi Arabia) on a diplomatic mission to the Soviet Union. Nazer also visited Egypt, Norway, the United States and Great Britain in an attempt to persuade those producers to reduce their oil output. The mission failed. The discussions in Great Britain and the United States, especially, demonstrated the significant difference in the interests of OPEC exporters, whose economies were dependent on oil income, and those two countries, whose economies were diversified. The United States Secretary of Energy, John S. Herrington, only worried that low prices could lead to increased US dependence on Persian Gulf oil. In July 1987, the president of OPEC, Rilwanu Lukman, criticized non-OPEC producers for overproduction, but he might just as well have addressed his remark to OPEC members themselves, among whom overproduction was widespread ${ }^{52}$.

In 1988, OPEC members continued their diplomatic efforts to reduce the global oil supply. In March of that year, seven oil exporters met in London to discuss cooperation with OPEC: Mexico, Oman, Egypt, China, Malaysia, Colombia and Angola. Norway, the Soviet Union and Brunei did not respond to the invitation, and after the London meeting Colombia withdrew. No agreement was reached. Later in 1988, OPEC concentrated on negotiating quotas among its own members. But scepticism about OPEC's ability to control prices was rising. The UAE oil minister, Mana Saeed Al-Otaiba, argued that the oil market itself was responsible for setting the price of oil. OPEC would be able to do so only together with all non-OPEC producers. While the oil ministers of other OPEC members preferred to blame the economic and fiscal policies of non-OPEC producers and Western countries for the deterioration in oil prices and the instability of the market, Al-Otaiba was convinced that the high oil prices of the previous decade were responsible for the oil glut ${ }^{53}$. Negotiations, instability and overproduction persisted up to the outbreak of the Iraq-Kuwait war and Iraq's occupation of Kuwait in 1990. The war provoked an immediate price rise fuelled by fears over the future geopolitical situation in the Persian Gulf and the future supply of oil to the market. On 6 August 1990, oil from Iraq and Kuwait was banned from the market, effectively reducing the global supply by 4 million

\footnotetext{
${ }^{47}$ Mabro, op. cit., p. 32.

${ }^{48}$ World Bank (2015): "Special Focus. Anatomy of the last four oil price crash", Commodity Markets Outlook.

${ }^{49}$ OPEC Annual Statistical Bulletin 2000, at

https://www.opec.org/opec_web/static_files_project/media/downloads/publications/ASB2000.pdf, p. 5.

${ }^{50}$ Stevens, Paul: "Resource impact: Curse or blessing? A literature survey", Journal of Energy Literature, Vol. 9 , No. 1 (June 2003), pp. 3-42.

${ }^{51}$ Gaidar, Yegor (2007): Collapse of an Empire: Lessons for Modern Russia, Washington, D.C., Brookings Institution Press.

${ }^{52}$ Shwadran, Benjamin: "Middle East Oil Developments", in Rabinovich, Itamar and Shaked, Haim (eds.) (1987): Middle East Contemporary Survey, Boulder - San Francisco - London, Westview Press, pp. 276-285

${ }^{53}$ Shwadran, Benjamin: "Middle East Oil Developments 1988", in Ayalon, Ami and Shaked, Haim (eds.) (1988):

Middle East Contemporary Survey, Boulder - San Francisco - London, Westview Press, pp. 309-332.
} 
$\mathrm{b} / \mathrm{d}^{54}$. This step allowed other producers to produce more; prices stabilised, and the conflicts within OPEC, and between OPEC and non-OPEC producers, subsided.

During the 1990s, oil prices were mostly stable - until they collapsed in 1998. This stability was achieved at a much lower level (especially in real terms) than had been the case in the early 1980s. OPEC members hoped that forecasts of a decline in the non-OPEC supply within five years would prove to be true. They didn't. That hope had to be pushed further off into the future because of improvements in exploration technology and large spare capacity ${ }^{55}$.

The second period of OPEC-non-OPEC negotiations started as the oil prices fall between October 1997 and April 1998 from $17 \mathrm{USD} / \mathrm{b}$ to $11.30 \mathrm{USD} / \mathrm{b}^{56}$. The consequence was a dramatic fall in the value of the petroleum exports of OPEC members, from 163.599 billion USD in 1997 to 107.352 billion USD in $1998^{57}$. Also, non-OPEC exporters suffered heavily. The price crash contributed to the financial crises in Russia ${ }^{58}$ and Indonesia ${ }^{59}$. Saudi Arabia engineered this price crash to stop Venezuela from developing its production capacity parallel to that of Saudi Arabia. According to the plan crafted in 1992 by the Venezuelan government, Venezuela was to achieve production capacity of 7 million b/d in 2010. Saudi Arabia was determined at any cost to stop it from raising production capacity to a level that would jeopardize the Kingdom's dominance on the market and the political power that went along with it. Saudi Arabia warned Venezuela numerous times that it would not accept its plans to increase production capacity. Since Venezuela failed to heed those warnings, Saudi Arabia reacted "aggressively and ruthlessly" to protect its dominant role on the oil market ${ }^{60}$.

Faced with falling prices, starting in January 1998 Mexico began working hard to reduce tensions between Venezuela and Saudi Arabia, and then between Mexico itself and Venezuela, in order to achieve production cuts and boost prices. After an agreement between these three countries was achieved, another non-OPEC supplier, Norway, was invited to negotiate. More than a year of patient oil diplomacy began ${ }^{61}$. Two oil agreements on production cuts were signed between OPEC and non-OPEC suppliers in 1998, but neither was implemented. In 1999, both groups of countries made another attempt. In March of that year, OPEC and four non-OPEC members (Mexico, Russia, Oman and Norway) agreed to cut production by 2.1 million b/d. Russia was to decrease its production by approximately $100,000 \mathrm{~b} / \mathrm{d}$, but in fact increased $\mathrm{it}^{62}$.

\footnotetext{
${ }^{54}$ Rachovich, David: "Middle East Oil Developments 1990", in Ayalon, Ami (ed.) (1992): Middle East Contemporary Survey, Boulder, Westview Press, pp. 277-299.

${ }^{55}$ Moody-Stuart, Mark: "Saudi Arabia and its role in oil markets", OIES Forum, no 100 (2015), pp. 19.; Chalabi, Fadhil (2010): Oil Policies, Oil Myths. Analysis and Memoir of an OPEC «Insider», London - New York, I.B. Tauris, p. 276.

${ }^{56}$ Mabro, op. cit., p. 5.

${ }^{57}$ OPEC Annual Statistical Bulletin 2000, at

https://www.opec.org/opec_web/static_files_project/media/downloads/publications/ASB2000.pdf, p. 5.

58 Åslund, Anders: "Russia's Financial Crisis: Causes and Possible Remedies", Post-Soviet Geography and Economics, Vol. 39, No. 6 (1998), pp. 309-328.

${ }^{59}$ Nasution, Anwar: "The Meltdown of the Indonesian Economy: Causes, Responses and Lessons", ASEAN Economic Bulletin, Vol. 17, No. 2 (August 2000), pp. 148-162.

${ }^{60}$ Soligo, Ronald and Jaffe, Amy Myers (2004): "Market structure in the new gas economy: Is cartelization possible?", Program on Energy and Sustainable Development at Stanford University/James A. Baker III Institute for Public Policy of Rice University, (2004), at https://www.bakerinstitute.org/media/files/Research/2d926cee/GAS_IsCartelizationPossible_12_2004.pdf.

${ }^{61}$ Lajous, Adrián: "The Mexican, Saudi, and Venezuelan connection - a memoir", OIES Forum, n' 100 (2015), pp. 4-11.

${ }^{62}$ Henderson, James and Fattouh, Bassam: "Russia and OPEC: Uneasy Partners", Oxford Energy Comment, (2016), at https://www.oxfordenergy.org/wpcms/wp-content/uploads/2016/02/Russia-and-OPEC-UneasyPartners.pdf?v=9b7d173b068d.
} 
The 1998 oil price crash confirmed that Saudi Arabia was not willing to act unilaterally. NonOPEC exporters were forced to cooperate with OPEC members in the face of declining income and the unwillingness of OPEC members to allow non-OPEC producers a free ride at OPEC's expense $^{63}$. In March 2000, OPEC succeeded as oil prices exceeded 30 USD/b. Impressed by its own success, OPEC decided to reverse its production cut of 1.7 million $\mathrm{b} / \mathrm{d}$. Also, a price band of 22-28 USD/b was introduced. In combination with slowing global economic growth, this step pushed prices down, and OPEC started to negotiate another production cut. It was ready to cut production provided non-OPEC producers (especially Russia) cooperated. But Russia behaved in a non-cooperative way, and OPEC and some non-OPEC exporters had to work on balancing the market without its support. In the late $1990 \mathrm{~s}$ and the early $21^{\text {st }}$ century, OPEC and non-OPEC producers were unable to arrive at any coherent, long-term strategy, and their activities contributed to increased market volatility ${ }^{64}$. Both groups of producers, however, did accumulate experience in cooperating.

\section{OPEC-non-OPEC cooperation 2016-2018}

OPEC's status has decreased in the $21^{\text {st }}$ century. Several factors have contributed to this development. First, OPEC is not an efficient cartel of nations steering the oil supply and prices. Second, in many OPEC member states, oil production has been declining for years. The main reasons for this are above-ground constraints. Third, OPEC oil production is dominated by national oil companies (NOCs), which are mostly inefficient. They lack capital and technology. The supply of energy to local consumers is heavily subsidized. Local governments are reluctant to cooperate with international oil companies (IOCs). Fourth, OPEC members suffer from a resource curse. Their budgetary needs can only be satisfied by oil revenue. In consequence, NOCs suffer from short-term political demands for money and are unable to develop and implement long-term investments. OPEC members' dependence on rising oil revenue makes their policies short-sighted ${ }^{65}$.

In the $21^{\text {st }}$ century, oil prices have become increasingly volatile. But importers and exporters react asymmetrically to volatility. The oil boom of 2002-2008 was met with a very weak political reaction by consuming countries. The reason for this was unprecedented growth rates in the global economy, whose energy intensity has been significantly reduced since the $1970 s^{66}$. At the same time, oil exporters continued to be dependent on oil income. Between July 2008 and February 2009, another price collapse took place, with a price drop of $77 \%$. No OPEC-non-OPEC deal was implemented, and OPEC reacted by making production cuts on its own $^{67}$.

In analysing OPEC-non-OPEC cooperation in the period 2016-2018, it is crucial to understand the behaviour of the most important player, Saudi Arabia. Its policy towards the oil market has to be understood as a mixture of short- and long-term thinking. The country's shortterm interest is in securing enough funds from oil exports to balance its budget. In the long

\footnotetext{
${ }^{63}$ Mabro, op. cit.

${ }^{64}$ Kohl, op. cit.

${ }^{65}$ IMF (2011): Gulf Cooperation Council Countries Enhancing Economic Outcomes in an Uncertain Global Economy, Washington, D.C., IMF.

${ }^{66}$ Segal, Paul: "Why Do Oil Price Shocks No Longer Shock?", OIES Working Paper, WPM 35 (2007), at https://ora.ox.ac.uk/objects/uuid:ca9ccad3-2814-4f57-8a80-

6a21367db214/download_file?file_format=pdf\&safe_filename=Why\%2Bdo\%2Boil\%2Bprice $\% 2 \mathrm{Bshocks} \% 2 \mathrm{Bn}$ o\%2Blonger\%2Bshock.pdf\&type_of_work=Working+paper.

${ }^{67}$ Henderson and Fattouh: op.cit.; World Bank (2015): "Special Focus. Anatomy of the last four oil price crash", op.cit.
} 
term, with its huge reserves, Saudi Arabia understands that its wealth is tied to global economic development and continuing or increased global demand for oil ${ }^{68}$.

The oil collapse that began in late 2014 features certain similarities with, but also some differences from, the previous crisis. The biggest differences are the rise and role of the shale oil industry, new directions of crude and petroleum product flows, the entry of new players with diversified business models, and new geopolitical risks. But some other features have not changed, including the problems of excess supply, rising levels of inventories, over-investment, OPEC's behaviour and its relationship with non-OPEC producers, the trade-off between maximizing revenue and gaining market share, and the role of market sentiment ${ }^{69}$.

In the second half of 2014, the expectation grew that OPEC would cut production. Unexpectedly, in November of that year its member states decided to keep it at 30 million $\mathrm{b} / \mathrm{d}^{70}$. In face of the lack of an OPEC reaction to the growing oversupply on the market, prices dropped by $51 \%$ between October 2014 and January $2015^{71}$.

The fall in prices since 2014 reminded the Saudi leadership of the experience of the 1980s. A slowdown in global oil consumption was observed. The global oil supply started to increase in non-OPEC countries, as well. Exploration in many high-cost areas, and the shale boom, started to change the balance of power on the market, creating a puzzle for Saudi Arabia. The first option was to cut production at the risk of losing market share, but keeping revenue high. The second option was to maintain market share, risking a decline in prices and revenue. Saudi Arabia had the experience of the 1980s in mind, and the deep understanding that it is better to stop the destruction of growth in demand sooner than later. Along with all the similarities with the 1980s, OPEC had to keep in mind three differences. First, there was now a new oil source, shale oil, which has different economic characteristics than conventional oil. Second, much attention was being paid to environmental issues. And third, the global economy was much more energy efficient than 30 years earlier ${ }^{72}$.

In December 2016, the former minister of petroleum and mineral resources of Saudi Arabia, Ali Al-Naimi, reported on the events of November 2014 during a discussion at the Center for Strategic \& International Studies. He pointed out two facts important to this analysis. First, he referred to a meeting of four countries (Saudi Arabia, Venezuela, Mexico, Russia) that took place before the OPEC conference. OPEC-non-OPEC consultations seemed to be the new norm, although in November 2014 it led to nothing conclusive. Second, Al-Naimi spoke of the discussion going on within OPEC. Representatives of all member states expressed their desire to cut production, yet at the same time pushed responsibility away from themselves. Consequently, Saudi Arabia refused to make unilateral cuts, and the fall in prices accelerated. Ali Al-Naimi also admitted that there was no long-term strategy at that moment to fight shale oil or high-cost oil producers. This came later as an explanation "to give our decision some dignity". He expressed the view that coordinated action among OPEC and non-OPEC exporters could lead to a balance between supply and demand, but with regard to the emerging OPECnon-OPEC agreement, and based on decades of previous experience with Russian oil policy, he expressed his scepticism about Russia's readiness to cut production. He was convinced that Saudi Arabia should not make cuts as it had in the 1980s. It had no power to unilaterally manage

\footnotetext{
${ }^{68}$ Haas, Pedro: "Saudi Arabia's complex relationship to the oil market: 1985 and 2015", OIES Forum, $\mathrm{n}^{\circ} 100$ (2015), pp. 25-29.

${ }^{69}$ Fattouh, Bassam: “The current oil price cycle and reflections on Mabro's work”, OIES Forum, n 100 (2015a), pp. 13.

${ }^{70}$ OPEC: “OPEC 166th Meeting concludes”, OPEC Press Release, no 7 (2014), at https://www.opec.org/opec_web/en/press_room/2938.htm.

${ }^{71}$ World Bank (2015): "Special Focus. Anatomy of the last four oil price crash", op cit.

${ }^{72}$ Haas: op.cit.
} 
the market and should not repeat the mistakes of the 1980s. Al-Naimi admitted that "Yamani was wrong" "73.

As indicated, the main driver of the oil price collapse was the growth of shale oil production in the United States. The shale revolution is a structural factor on the market. It makes available a new type of unexplored resources. Shale oil is produced in an oil importing country interested in moderate oil prices. Additionally, the economics of shale oil were unknown, and could change fast. As suggested in the literature, OPEC, and more specifically Saudi Arabia, was well advised to assume that shale oil production was price elastic, and to maintain production ${ }^{74}$. Behind the scenes, months of diplomatic searching for an agreement on production began. The key elements had to be: 1) the readiness of Saudi Arabia to cut production, 2) the readiness of other OPEC members to take on some of the burden, and 3) the readiness of non-OPEC suppliers to cut production. Importantly, however, there was a complete lack of trust among participants. Ali Al-Naimi openly demanded a market share for low-cost producers. He also indicated the technical problems that many producers faced (especially Russia in West Siberia) in regulating production levels. His remarks were confrontational towards high-cost producers ${ }^{75}$. The readiness of Saudi Arabia to fight a price war was strengthened by its huge financial reserves and low debt-to-GDP ratio, things that had been achieved thanks to responsible financial policy during the boom. The financial position of most of the oil exporters with exception of the United Arab Emirates, Kuwait and Qatar, was much weaker ${ }^{76}$.

In 2015, OPEC members were not able to take a pro-active stance. In June, they decided to stick to a production ceiling of 30 million $\mathrm{b} / \mathrm{d}^{77}$, but by the time OPEC met in November, its members did not even include any information on the production ceiling in the conclusions from the meeting. The disagreement among them was too big, and the figure of 30 million b/d was no longer relevant; OPEC was producing considerably more than that $^{78}$.

The price collapse had a tremendous effect on the economies of oil exporting countries, as they are still dominated by the oil sector. In many of them, the ratio of oil rents to GDP exceeds $10 \%$. This applies equally to OPEC (i.a. Iraq, Kuwait, Saudi Arabia, Angola, Iran, UAE, Venezuela) and to non-OPEC countries (i.a. Oman, Azerbaijan, Kazakhstan). But also, in the case of exporters whose ratio of oil rents to GDP is lower, such as Russia, the energy sector is the heart of economic life. Although oil rents were equal to only $6.4 \%$ of GDP in 2017 in Russia $^{79}$, the proportion of revenue obtained from oil and gas sector taxation was almost $40 \%$

\footnotetext{
${ }^{73}$ Al-Naimi: op.cit.

${ }^{74}$ Fattouh, Bassam; Poudineh, Rahmatallah and Sen, Anupama: "The Dynamics of the Revenue MaximizationMarket Share Trade-Off: Saudi Arabia's Oil Policy in the 2014-2015 Price Fall”, OIES Working Paper, No. WPM 61 (2015), at

https://www.oxfordenergy.org/wpcms/wp-content/uploads/2015/10/WPM-61.pdf?v=9b7d173b068d.

75 Tully, Andy: "Oil Minister Says Saudi Will Never Cut Production Regardless of Price”, Oilprice, 23 December 2014, at https://oilprice.com/Latest-Energy-News/World-News/Oil-Minister-Says-Saudi-Will-Never-CutProduction-Regardless-Of-Price.html

${ }^{76}$ Fattouh, Bassam: "Current Oil Market Dynamics and the Role of OPEC: Reflections on Robert Mabro's Work", Oxford Institute for Energy Studies, (2015b), at https://www.oxfordenergy.org/wpcms/wpcontent/uploads/2015/01/Current-Oil-Market-Dynamics-and-the-Role-of-OPEC-Reflections-on-Robert-MabrosWork.pdf

77 OPEC: "OPEC 167th Meeting concludes”, OPEC Press Release, No 3 (2015), at https://www.opec.org/opec_web/en/press_room/3046.htm

78 OPEC: "OPEC 168th Meeting concludes", OPEC Press Release, No 8 (2015), at https://www.opec.org/opec_web/en/press_room/3193.htm.

${ }^{79}$ World Bank (2017): "Oil rents (\% of GDP)", World Bank Data, at https://data.worldbank.org/indicator/NY.GDP.PETR.RT.ZS?end=2017\&most_recent_value_desc=true \&start=20 00
} 
of the federal budget. During period of high prices in the early $2010 \mathrm{~s}$, it reached almost $50 \%{ }^{80}$. Consequently, as oil prices crashed, exporters went from budget surpluses to budget deficits, and many of them from a current account surplus into a deficit. Spending had to be restricted, new taxes introduced, and tax exemptions eliminated. Some of these countries, after years of absence, came back to the bond market to seek financing ${ }^{81}$. The fall of prices to a level of 30 USD/b in the early 2016 meant that the price didn't cover the average total cost of production ${ }^{82}$ (i.a. Norway, Angola, Colombia, Nigeria) or was only equal to it (i.a. Mexico, Kazakhstan, Venezuela) for multiple producers. With a dramatically reduced profit margin, the most efficient producers ${ }^{83}$ were also forced to analyse again their market strategy.

2016 was a year of diplomatic efforts to find some agreement among producers. In February, at a meeting of their ministers responsible for the oil sector, Ali Al-Naimi of Saudi Arabia and Alexander Novak of Russia declared their readiness to freeze production. Qatar and Venezuela also participated in the meeting. Ali Al-Naimi declared that the potential freeze would be just the beginning of the process, and that other countries would be expected to join in. The consequence was another summit in Doha in April, where no agreement on freezing production was reached. The main obstacle was that Iran was coming back to the market after having had sanctions imposed on it, and wanted to increase its market share. The Doha summit was the last that Ali Al-Naimi attended as minister. His successor, Khalid Al-Falih, appointed in May 2016, shifted the interest from a freeze to a cut in oil production. He declared that OPEC should "steward the market". First, during a meeting in Algiers, OPEC members were able to reach a preliminary agreement about production cuts. Libya and Nigeria were to be exempted, and Iran to be given dispensation. Of key importance was the dialogue with Russia. On 30 November 2016, OPEC agreed to a production cut of around 1.2 million b/d. It was also informed that non-OPEC producers (Azerbaijan, Bahrain, Brunei, Equatorial Guinea, Kazakhstan, Malaysia, Mexico, Oman, Russia, Sudan and South Sudan) would cut their production by 0.558 million b/d. A Ministerial Monitoring Committee was established to oversee the agreement, signed for a duration of 6 months. The declared goal was to achieve a balance of supply and demand on the market and to reduce the stocks overhang of oil ${ }^{84}$. A Declaration of Cooperation was signed on 10 December 2016, giving birth to the OPEC+ agreement $^{85}$.

Members of the agreement implemented the production cuts. An important event in bringing Russia closer to OPEC was a meeting between the crown prince of Saudi Arabia, Mohammad bin Salman Al Saud, and the president of Russia, Vladimir Putin, on the sidelines of the G20 meeting in China in September 2016. And a symbol of the rapprochement between Russia and Saudi Arabia was a visit by the King of Saudi Arabia to Russia in October 2017, the

\footnotetext{
${ }^{80}$ Kluge, Janis: "Mounting Pressure on Russia's Government Budget. Financial and Political Risks of Stagnation”, SWP Research Paper, no 2 (February 2019), at https://www.swp-berlin.org/fileadmin/contents/products/research_papers/2019RP02_klg.pdf, p. 8.

${ }^{81}$ Sommer, Martin; Treviño, Juan and Hickey, Neil: "Oil Exporters Learn to Live with Cheaper Oil”, IMF, 8 June 2016, at <https://blogs.imf.org/2016/06/08/oil-exporters-learn-to-live-with-cheaper-oil/\#more-13038>.; IMF (2017): The Economic Outlook and Policy Challenges in the GCC Countries, Washington, D.C., IMF.

${ }^{82}$ The total cost includes capital and operational expenditures. Operational expenditures were below 20 USD/b for all the indicated countries.

${ }^{83}$ Statista (2019): "Production cost breakdown of one barrel of oil in the top oil producing nations", Statista Research Department, at https://www.statista.com/statistics/597669/cost-breakdown-of-producing-one-barrel-ofoil-in-the-worlds-leading-oil-producing-countries

84 OPEC: "OPEC 171st Meeting concludes", OPEC Press Release, no 24 (2016), at https://www.opec.org/opec_web/en/press_room/3912.htm.

85 OPEC: "OPEC and non-OPEC Ministerial Meeting", OPEC Press Release, no 25 (2016), at https://www.opec.org/opec_web/en/press_room/3944.htm
} 
first-ever such visit in history. The new Russian-Saudi alliance has been observed with interest by OPEC members, as power has shifted from OPEC itself towards Russia and Saudi Arabia ${ }^{86}$.

The reduction in production was bigger than expected, and pushed prices high. The level of conformity by the agreement's signatories reached 147\% in May 2018. In June, they decided to come back to a conformity of $100 \%$, which effectively meant an increase in production ${ }^{87}$. The mid-term consequence of the OPEC+ production reduction was a rise of production in some countries not participating in the agreement, most of all in the USA. The recovery in the US shale industry had a significant impact on the balance on the global market. In December 2017, the IEA forecast a fall in demand for OPEC oil, by 0.4 million b/d in 2018, which turned out to be 1.2 million b/d. The average rise in the US oil supply in late 2017 was anticipated to be around 1 million b/d, but proved to be about 2 million $\mathrm{b} / \mathrm{d}$. As information about rising production in the USA spread, prices went down. The signatories to the OPEC+ agreement were again confronted with an oversupply on the market and falling prices. They could choose to finish cooperation and allow prices to fall, or could continue cooperation, which was equal to further production cuts ${ }^{88}$. They understood that the restriction in their production was one of the reasons behind the revival of the US shale industry ${ }^{89}$, but due to budgetary needs and the desire to manage the oil market, their decided to cut production further. During the 5th OPEC and non-OPEC Ministerial Meeting, they decided on a production cut of about 1.2 million $\mathrm{b} / \mathrm{d}^{90}$. Overall, the compliance of OPEC+ agreement members is at a very high level. Yet it is worth remembering that this has also been achieved through cuts in oil production in Venezuela, Mexico and Angola that are not fully voluntary. The under-investment that resulted from the price war of 2014-2016 led to a reduction in production capacity ${ }^{91}$. In 2015 , the global upstream investment in the oil and gas sector fell by 25\% against 2014, and in 2016 fell again by $26 \%$ against 2015. Since then, the investment value has been growing on year-on-year, but only within the single digit range. Simultaneously, the USA's share in global upstream investments in the oil and gas sector increased during 2008-2018, from $17 \%$ to $24 \%$, leaving the future potential of many traditional exporters in question ${ }^{92}$. The production cuts did not fully achieve their aim. The growing supply from the USA pushed OPEC+ members to a third decision on a production cut in December $2019^{93}$.

The fragile market balance has been put under further pressure by the outbreak of Covid19, which has spread in Asia, Europe and the USA. As a result, there has been an economic slow-down, and forecasts indicate the first drop in global oil demand since 2009. Faced with this high level of uncertainty, OPEC+ producers started discussing further production cuts. Unexpectedly, those negotiations failed because of disagreement between Russia and Saudi

\footnotetext{
${ }^{86}$ Raval, Anjli and Foy, Henry: "Russia and Saudi reaffirm Opec oil supply cut pledge", Financial Times, 5.10.2017, at https://www.ft.com/content/636f384c-a9d9-11e7-ab55-27219df83c97

${ }^{87}$ OPEC: "The 4th OPEC and non-OPEC Ministerial Meeting concludes", OPEC Press Release, no 14 (2018), at https://www.opec.org/opec_web/en/press_room/5081.htm

${ }^{88}$ Lynch, Michael: "What Happened To Oil Prices In 2018?”, Forbes, 2 January 2019, at https://www.forbes.com/sites/michaellynch/2019/01/02/what-happened-to-oil-prices-in-2018/\#13230e296d83

${ }^{89}$ Barkindo, Mohammad. S.: “OPEC within the global energy transition”, OPEC Press Release, (March 2019), at https://www.opec.org/opec_web/en/press_room/5411.htm

${ }^{90}$ OPEC: "The 5th OPEC and non-OPEC Ministerial Meeting concludes", OPEC Press Release, no 28 (2018), at https://www.opec.org/opec_web/en/press_room/5279.htm

${ }^{91}$ Wingfield, Brian; Dodge, Samuel and Sam, Cedric: "OPEC and Allies Part Ways on Oil Cuts", Bloomberg, 15

August 2018, at https://www.bloomberg.com/graphics/opec-production-targets/

${ }^{92}$ IEA (2019): World Energy Investment 2019, Paris, International Energy Agency, pp. 83-94.

${ }^{93}$ OPEC: "The 7th OPEC and non-OPEC Ministerial Meeting concludes", OPEC Press Release, no 14 (2019), at https://www.opec.org/opec_web/en/press_room/5797.htm.
} 
Arabia. Saudi Arabia pushed for a collective additional cut of 1.5 million b/d $\mathrm{d}^{94}$, but Russia refused. Two arguments have been repeated in media coverage of the talks. First, the production restrictions self-imposed by OPEC+ members since 2017 have led to price increases and increased production in the USA. OPEC+ subsidizes high cost producers, including dynamic shale oil producers. Second, as the USA has hit companies engaged in North Stream II pipeline and Russia's biggest oil company, Rosneft, with sanctions the Russian authorities decided to weaken US shale oil producers by provoking a price $\operatorname{crash}^{95}$. The third argument was raised by Pavel Sorokin, Russia's deputy energy minister, who argued in an interview with the press agency Reuters that Russia didn't want to get caught up in a circle of repeating production cuts and that, where there is great uncertainty about future demand, market forces are the best instrument for bringing the market back into balance. He also underlined that all communication channels between Russia and Saudi Arabia, and Russia and OPEC, are open ${ }^{96}$. Leaving the reasons for the disagreement aside, Saudi Arabia immediately decided to increase production and cut prices, starting a new price war and provoking the biggest one-day price fall since the Gulf War in the early 1990s. Between the beginning of 2020 and mid-March prices fell by more than half, below $30 \mathrm{USD} / \mathrm{b}$ for Brent, starting a discussion about the victims of the price crash. US shale oil producers, Iraq, Nigeria, Algeria, Oman, Angola, Azerbaijan and Ecuador are without doubt the most threatened ${ }^{97}$, although there is a strong consensus that all producers will be hurt. Russia and Saudi Arabia have declared their readiness for a long period of low oil prices $^{98}$, but are rather hoping for a fast drop in production in the USA and other high-cost regions.

\section{Towards institutionalization?}

By October 2017, attention had moved from short-term oil market management towards the institutionalization of cooperation ${ }^{99}$. A key element was whether the OPEC+ agreement is just a short-term project to reduce supply and inventories and raise prices, or whether it will become a long-term deal understood as a realignment of the global oil industry.

OPEC members have wanted to develop sustainable cooperation, and non-OPEC exporters understood that they could not go on having a free ride at OPEC members' expense. Some of them (such as Russia) became interested in strengthening their international prestige through their participation in the OPEC + agreement. They probably also hope that the USA's opposition to further market cartelization would weaken due to its newly won strength as an energy power.

A hint about the work being undertaken to build a long-term agreement between OPEC and non-OPEC producers was given in 2018 by the president of OPEC, Suhail Al Mazroui, also the minister of energy and industry of the UAE. He let it be known that the aim was "to put

\footnotetext{
${ }^{94}$ OPEC: “OPEC 178th (Extraordinary) Meeting of the Conference concludes”, OPEC Press Release, $\mathrm{n}^{\circ} 3$ (2020), at https://www.opec.org/opec_web/en/press_room/5865.htm

${ }^{95}$ Glosserman, Brad: "Egos and U.S. fracking trigger Russia-Saudi oil price war", The Japan Times, 16 March 2020, at https://www.japantimes.co.jp/opinion/2020/03/16/commentary/world-commentary/egos-u-s-frackingtrigger-russia-saudi-oil-price-war/\#.XnCWtHJCdPZ

${ }^{96}$ Astakhova, Olesya and Golubkova, Katya: "Exclusive: Russia to OPEC - deeper oil cuts won't work", Reuters, 11 March 2020, at https://www.reuters.com/article/us-oil-opec-russia-exclusive/exclusive-russia-to-opec-deeperoil-cuts-wont-work-idUSKBN20Y2TJ

${ }^{97}$ Gould, Tim and Al-Saffar, Ali: "Energy market turmoil deepens challenges for many major oil and gas exporters", IEA, 16 March 2020, at https://www.iea.org/articles/energy-market-turmoil-deepens-challenges-formany-major-oil-and-gas-exporters

${ }^{98}$ Seddon, Max: "Russia says it can deal with pain of a Saudi oil price war", Financial Times, 9 March 2020, at https://www.ft.com/content/4009472c-620e-11ea-b3f3-fe4680ea68b5

${ }^{99}$ Barkindo, Mohammad. S.: "The Current Oil Market Outlook and beyond", OPEC Press Release, (October 2017), at https://www.opec.org/opec_web/en/press_room/4582.htm
} 
[...] a draft agreement for this group [of 24] to stay together for a longer time". He expressed the wish that, by the end of 2018, all participants of the OPEC+ agreement would sign a new draft framework. Al Mazroui was joined by the secretary general of OPEC, Mohammed Barkindo, in his attempts to institutionalize cooperation. Al Mazroui indicated that, during 2017, members of OPEC + had learnt how to cooperate with each other and a process of building trust between them had taken place. He praised their ability to put aside their non-oil-related differences and concentrate on managing the oil market. In January 2018, Khalid Al-Falih argued that the alliance between Russia and Saudi Arabia would last for "decades and generations" "100. In March 2018, Saudi Crown Prince Mohammed bin Salman announced that Saudi Arabia and Russia were working to shift from year-to-year agreements towards " $a$ 10- to 20-year agreement". Speaking at a US-Saudi business forum in New York, Al-Falih praised the OPEC+ agreement as a success of Saudi Arabia's leadership in the oil market, and advocated for its role in long-term oil market management ${ }^{101}$. Also, in June 2018, the Russian energy minister, Alexander Novak, argued in favour of OPEC+ agreement institutionalization. Russia and Saudi Arabia have invited all participants to engage in further cooperation. The plans include a new institution with its own constitution and secretariat. It could have a different voting system than OPEC (which operates on the principle of one 'country, one vote'), with more rights for larger producers ${ }^{102}$.

But in December 2018, the Russian narrative towards a long-term agreement, and especially institutionalization, started to change. Alexander Novak said there would be no new organization due to the danger of unnecessary bureaucratisation and anti-cartel legislation in the USA. Russia began to see OPEC+ agreement more as a mechanism of cooperation than an international organisation, as a discussion forum adopting memorandums and joint resolutions ${ }^{103}$. Despite this, Khalid Al-Falih gave his assurances during the 13th Meeting of the JMMC on 18 March 2019 in Baku "that the development of the longer-term Charter of Cooperation has been proceeding satisfactorily (...)."104.

The responsiveness of the US shale industry to price signals ${ }^{105}$, and its production potential, raise doubts as to the sense of market management by the countries united in the OPEC+ agreement. Such voices have been loudest primarily in Russia, having been expressed by Igor Sechin, the Russian oil company Rosneft's CEO ${ }^{106}$. Despite those doubts, in 2019 members of the OPEC+ agreement revealed a draft text of the Charter of Cooperation defined as a "voluntary commitment, to enable the continued proactive dialogue between countries in

\footnotetext{
100 Alrawiand, Mustafa and Gnana, Jennifer: "Exclusive: Plans in the works for super group of oil producing countries", The National, 15 February 2018, at https://www.thenational.ae/business/energy/exclusive-plans-inthe-works-for-super-group-of-oil-producing-countries-1.705004

101 Raval, Anjli: "Opec and Russia considering 10-20 year oil alliance", Financial Times, 27.3.2018, at <https://www.ft.com/content/6788ffe8-31de-11e8-ac48-10c6fdc22f03>.

102 Kennedy, Will; Mazneva, Elena and Mahdi, Wael: "Russia-Saudi plans for Super-OPEC could reshape global oil order", Financial Post, 22 June 2018, at https://business.financialpost.com/commodities/energy/russia-saudiplans-for-super-opec-could-reshape-global-oil-order

103 Cheikh, Meissa: "OPEC+ Will Not Be Formalized", Energy Services Experts, 28 December 2018, at https://www.energyservicesexperts.com/2018/12/28/opec-will-not-be-formalized/.; Jaffe, Amy M.: "How Will the U.S. Respond to Russia-OPEC Cooperation?", CFR, 14 December 2019, at https://www.cfr.org/article/howwill-us-respond-russia-opec-cooperation.

104 Al-Falih, Khalid A.: "Remarks by HE Khalid A. Al-Falih Minister of Energy, Industry \& Mineral Resources of the Kingdom of Saudi Arabia", OPEC Press Release, (March 2019), at https://www.opec.org/opec_web/static_files_project/media/downloads/press_room/Remarks\%20by\%20Chairma n\%20of\%20the\%20JMMC\%20HE\%20Al-Falih\%20Baku\%20March\%202019.pdf

105 IEA (2019): Oil Market Report: 2020 vision, Paris, International Energy Agency.

106 "Russia's Rosneft discusses govt compensation for OPEC deal extension - agencies", Reuters, 4 June 2019, at https://www.reuters.com/article/oil-opec-russia-sechin/update-1-russias-rosneft-discusses-govt-compensationfor-opec-deal-extension-agencies-idUSL8N23B2FW.
} 
the Declaration of Cooperation". Looking at the text of the Charter of Cooperation, it is clear that deeper institutionalisation has failed to materialize ${ }^{107}$. The cooperation of exporters within OPEC+ is non-formalized, based on government-to-government negotiations, and flexible. OPEC + should be seen as a summit process.

\section{Conclusions}

The oil crisis of 1973 gave OPEC an illusion of market power. This was reinforced by the second oil crisis. But, as from 1982, OPEC members began to contact non-OPEC producers, seeking agreement on production levels in order to manage the global oil supply and oil prices. In the following decades, OPEC nurtured its image of being an oil cartel. But in fact, whenever oil prices collapsed, it tried to reach an agreement with non-OPEC producers, being very reluctant towards taking unilateral action. As a consequence of the price wars of the mid-1980s and 1998, many non-OPEC producers joined OPEC in an effort to manage the oil market. Also, during the oil price collapse that began in 2014, OPEC - or more specifically its most important member, Saudi Arabia - again resisted unilateral action. To win cooperation from other exporters, it was willing to start a price war. First, in November/December 2016, OPEC and the non-OPEC producers agreed on coordinated oil production cuts. The OPEC+ agreement was born. Since then, it has emerged as a new governor in GEG. In July 2019, its Charter of Cooperation was signed. The signatories to the OPEC + agreement decided to avoid founding any formal IGO, and OPEC + continues to exist as a summit process. The OPEC+ agreement represents a shift in global market power towards the biggest producers and exporters, mainly Saudi Arabia and Russia. Mid-sized OPEC producers have been marginalized. The prolonged period of moderate oil prices and the uncertain future of those prices are limiting investments in their oil industries, further strengthening the importance of Saudi Arabia, Russia, and the small group of Persian Gulf low-cost producers. The price war that started in March 2020 can only accelerate this process. The OPEC+ agreement is being built on the basis of interstate relations between the strongest producers, with OPEC's importance waning. The formation and institutionalization of the OPEC + agreement is a sign of a restructuring taking place in the architecture of GEG.

What are the advantages of OPEC+? It has a bigger market share. Russia alone is responsible for over $10 \%$ of global oil production. OPEC+'s ability to influence the oil market is bigger than that of OPEC. But above all, OPEC+ is bring participating countries political benefits as members of an institution that controls half of the global oil supply. For decades, Saudi Arabia was the dominant player. As a consequence of the OPEC+ agreement, it now shares this role with Russia.

But problems for OPEC + remain, the first of which is compliance. Between 2017 and March 2020, this was at a healthy level, largely due to the discipline of individual countries such as Saudi Arabia, Kuwait, UAE and Russia, as well as to involuntary production cuts in Venezuela, Mexico and Angola. Venezuela became the biggest victim of the price war of 20142016, which caused economic chaos in the country. OPEC+ has no instrument with which to control production. Due to dwindling demand in early 2020, Russia and Saudi Arabia have begun a price war, hoping to eliminate weaker producers and accumulate more power in their own hands. Price wars remain the only method the most powerful exporters can use to manage the market.

The second problem is that some big producers remain outside the organization; the USA, Canada and Brazil are the most important of these, and the US's shale industry presents an especially difficult challenge to any attempt to limit global supply. The membership issue in

107 OPEC: "The 6th OPEC and non-OPEC Ministerial Meeting concludes", OPEC Press Release, n' 7 (2019), at https://www.opec.org/opec_web/en/press_room/5594.htm 
the OPEC+ agreement was only minimalized against OPEC. In the near future, US shale oil will be the biggest factor contributing to supply growth. Shale oil producers are price sensitive, keen to respond to higher prices.

Finally, OPEC's image of being a powerful organization is rooted in the successful fourfold rise of oil prices in 1973 to a new record. The signatories of the OPEC+ agreement can only confirm their ability to partially rebuild oil prices. The price war of 2020 is damaging this picture, with some analysts already seeing it as the end of OPEC + . In the 1970s, OPEC countries were successful in remodelling the global oil market and in their struggle for power. The OPEC+ agreement is defensive in nature. It has helped oil exporters to rescue their revenue.

Despite these weaknesses, OPEC+ may become an important governor in GEG, gradually diminishing the importance of OPEC. As long as Saudi Arabia and Russia are cooperating, they have a better chance of coordinating the global supply and reducing price volatility. But a reduction in price volatility should not be misunderstood as price setting. On the oil market, political and economic forces clash. The lesson that OPEC learned and passed on to OPEC + is that producers cannot eliminate market forces. The price crash of March 2020 shows that neither Russia nor Saudi Arabia are under the illusion that OPEC+ has power over market forces.

\section{Bibliography}

Al-Falih, Khalid A.: "Remarks by HE Khalid A. Al-Falih Minister of Energy, Industry \& Mineral Resources of the Kingdom of Saudi Arabia", OPEC Press Release, (March 2019), at https://www.opec.org/opec_web/static_files_project/media/downloads/press_room/Remarks $\% 20$ by $\% 20$ Chairman\%20of\%20the\%20JMMC\%20HE\%20AlFalih\%20Baku\%20March\%202019.pdf

Al-Naimi, Ali Ibrahim: “A Discussion with His Excellency Ali Ibrahim Al-Naimi”, Center for Strategic \& International Studies, 2 December 2016, at https://www.csis.org/events/discussionhis-excellency-ali-ibrahim-al-naimi

Adelman, Morris A.: "Efficiency of Resource Use in Crude Petroleum", Southern Economic Journal, Vol. 31, no 2 (October 1964), pp. 101-122.

Adelman, Morris A.: “The Clumsy Cartel”, The Energy Journal, Vol. 1, nº 1 (January 1980), pp. 43-53.

Adelman, Morris A.: “The Real Oil Problem”, Regulation, Vol. 27, n 1 (Spring 2004), pp. 1621.

Alrawiand, Mustafa and Gnana, Jennifer: "Exclusive: Plans in the works for super group of oil producing countries", The National, 15 February 2018, at https://www.thenational.ae/business/energy/exclusive-plans-in-the-works-for-super-group-ofoil-producing-countries-1.705004?videoId=5771275459001

Åslund, Anders: "Russia's Financial Crisis: Causes and Possible Remedies", Post-Soviet Geography and Economics, Vol. 39, nº 6 (1998), pp. 309-328. 
Astakhova, Olesya and Golubkova, Katya: "Exclusive: Russia to OPEC - deeper oil cuts won't work", Reuters, 11 March 2020, at https://www.reuters.com/article/us-oil-opec-russiaexclusive/exclusive-russia-to-opec-deeper-oil-cuts-wont-work-idUSKBN20Y2TJ

Baccini, Leonardo; Lenzi Veronica and Thurner, Paul W.: "Global Energy Governance: Trade, Infrastructure, and the Diffusion of International Organizations", International Interactions. Empirical and Theoretical Research in International Relations, Vol. 39, $\mathrm{n}^{\circ} 2$ (2013), pp. 192216.

Barkindo, Mohammad. S.: "The Current Oil Market Outlook and beyond", OPEC Press Release, (October 2017), at <https://www.opec.org/opec_web/en/press_room/4582.htm>.

Barkindo, Mohammad. S.: "OPEC within the global energy transition", OPEC Press Release, (March 2019), at https://www.opec.org/opec_web/en/press_room/5411.htm

Blaydes, Lisa: "Rewarding Impatience: A Bargaining and Enforcement Model of OPEC", International Organization, Vol. 58, n 2 (Spring 2004), pp. 213-237.

Cameron, Maxwell A. and Tomlin, Brian W. (2000): The Making of NAFTA. How the Deal Was Done, Ithaca - London, Cornell University Press.

Chalabi, Fadhil (2010): Oil Policies, Oil Myths. Analysis and Memoir of an OPEC «Insider», London - New York, I.B. Tauris.

Claes, Dag H. (2001): The Politics of Oil-producer Cooperation, Boulder, Westview Press.

Claes, Dag H. (2018a): The Politics of Oil: Controlling Resources, Governing Markets and Creating Political Conflicts, Cheltenham, Edward Elgar Publishing.

Claes, Dag H. (2018). Saudi Arabia and OPEC: Governing the World Energy Regime, Paper to be presented at the 59th Annual Convention International Studies Association.

Colgan, Jeff D.: "The Emperor Has No Clothes: The Limits of OPEC in the Global Oil Market", International Organization, Vol. 68, no 3 (Summer 2014), pp. 599-632.

Colgan, Jeff D.; Keohane, Robert O. and Van de Graaf, Thijs: "Punctuated equilibrium in the energy regime complex", Review of International Organizations, Vol. 7, no 2 (2012), pp. 117 143.

Cheikh, Meissa: "OPEC+ Will Not Be Formalized", Energy Services Experts, 28 December 2018, at https://www.energyservicesexperts.com/2018/12/28/opec-will-not-be-formalized/

Elass, Jareer and Jaffe, Amy M.: "The History and Politics of Russia's Relations with OPEC", James A. Baker III Institute for Public Policy of Rice University, (2009), at https://scholarship.rice.edu/bitstream/handle/1911/91409/EF-pub-ElassJaffeRussiaOPEC050609.pdf? sequence $=1 \&$ isAllowed $=\mathrm{y}$.

ElBaradei, Mohamed: "A global agency is needed for the energy crisis", Financial Times, 23 July 2008, at https://www.ft.com/content/b3630dd0-58b5-11dd-a093-000077b07658

Fattouh, Bassam: “An Anatomy of the Crude Oil Pricing System”, OIES Working Paper, WPM 40 (2011), at

https://www.oxfordenergy.org/wpcms/wp-content/uploads/2011/03/WPM40-

AnAnatomyoftheCrudeOilPricingSystem-BassamFattouh-2011.pdf

Fattouh, Bassam and van der Linde, Coby (2011): The International Energy Forum. Twenty years of producer-consumer dialogue in a changing world, Riyadh, IEF.

Fattouh, Bassam; Poudineh, Rahmatallah and Sen, Anupama: "The Dynamics of the Revenue Maximization-Market Share Trade-Off: Saudi Arabia's Oil Policy in the 2014-2015 Price 
Fall”, OIES Working Paper, WPM 61 (2015), at https://www.oxfordenergy.org/wpcms/wpcontent/uploads/2015/10/WPM-61.pdf?v=9b7d173b068d.

Fattouh, Bassam: "The current oil price cycle and reflections on Mabro's work", OIES Forum, $\mathrm{n}^{\mathrm{o}} 100$ (2015a), pp. 13-16.

Fattouh, Bassam: "Current Oil Market Dynamics and the Role of OPEC: Reflections on Robert Mabro's Work", Oxford Institute for Energy Studies, (2015b), at https://www.oxfordenergy.org/wpcms/wp-content/uploads/2015/01/Current-Oil-MarketDynamics-and-the-Role-of-OPEC-Reflections-on-Robert-Mabros-Work.pdf

Florini, Ann and Sovacool, Benjamin K.: "Who governs energy? The challenges facing global energy governance", Energy Policy, Vol. 37, n 12 (December 2009), pp. 5239-5248.

Gaidar, Yegor (2007): Collapse of an Empire: Lessons for Modern Russia, Washington, D.C., Brookings Institution Press.

Glosserman, Brad: "Egos and U.S. fracking trigger Russia-Saudi oil price war", The Japan Times, 16 March 2020, at

https://www.japantimes.co.jp/opinion/2020/03/16/commentary/world-commentary/egos-u-sfracking-trigger-russia-saudi-oil-price-war/\#.XnCWtHJCdPZ>

Goldthau, Andreas and Witte, Jan Martin (eds.) (2010): Global Energy Governance. The new rules of the game, Washington, D.C., Brookings Press.

Gould, Tim and Al-Saffar, Ali: "Energy market turmoil deepens challenges for many major oil and gas exporters", IEA, 16 March 2020, at https://www.iea.org/articles/energy-marketturmoil-deepens-challenges-for-many-major-oil-and-gas-exporters

Gray, Julia: "Life, Death, or Zombie? The Vitality of International Organizations", International Studies Quarterly, Vol. 62, nº 1 (March 2018), pp. 1-13.

Grayson, George (1988): Oil and Mexican Foreign Policy, Pittsburgh, University of Pittsburgh Press.

Green, Jessica F. and Colgan, Jeff: "Protecting Sovereignty, Protecting the Planet: State Delegation to International Organizations and Private Actors in Environmental Politics", Governance, Vol. 26, nº 3 (July 2013), pp. 473-497.

Grieco, Joseph M.: "Anarchy and the Limits of Cooperation: A Realist Critique of the Newest Liberal Institutionalism", International Organization, Vol. 42, nº 3 (Summer 1988), pp. 485507.

Griffin, James M. and Neilson, William S.: "The 1985-86 oil price collapse and afterwards: what does game theory add?", Economic Inquiry, Vol. 32, no 4 (October 1994), pp. 543-561.

Haas, Pedro: "Saudi Arabia's complex relationship to the oil market: 1985 and 2015", OIES Forum, no 100 (2015), pp. 25-29.

Henderson, James and Fattouh, Bassam: "Russia and OPEC: Uneasy Partners", Oxford Energy Comment, (2016), at

https://www.oxfordenergy.org/wpcms/wp-content/uploads/2016/02/Russia-and-OPECUneasy-Partners.pdf?v=9b7d173b068d.

Hnyilicza, Esteban and Pindyck, Robert S.: "Pricing policies for a two-part exhaustible resource cartel: The case of OPEC", European Economic Review, Vol. 8, n 2 (August 1976), pp. 139154.

IEA (2018): Oil 2018. Analysis and Forecasts to 2023, Paris, International Energy Agency. 
IEA (2019): World Energy Investment 2019, Paris, International Energy Agency.

IEA (2019): Oil Market Report: 2020 vision, Paris, International Energy Agency.

Ikenberry, John G. (1988): Reasons of State: Oil Politics and the Capacities of American Government, Ithaca - London, Cornell University Press.

IMF (2011): Gulf Cooperation Council Countries Enhancing Economic Outcomes in an Uncertain Global Economy, Washington, D.C., IMF.

IMF (2017): The Economic Outlook and Policy Challenges in the GCC Countries, Washington, D.C., IMF.

Jaffe, Amy M.: "How Will the U.S. Respond to Russia-OPEC Cooperation?", CFR, 14 December 2019, at <https://www.cfr.org/article/how-will-us-respond-russia-opeccooperation>.

Kennedy, Will; Mazneva, Elena and Mahdi, Wael: "Russia-Saudi plans for Super-OPEC could reshape global oil order", Financial Post, 22 June 2018, at https://business.financialpost.com/commodities/energy/russia-saudi-plans-for-super-opeccould-reshape-global-oil-order

Kérébel Cécile and Keppler Jan Horst (2009): La gouvernance mondiale de l'énergie, Paris, IFRI.

Kirton, John: "The G8 and Global Energy Governance: Past Performance, St. Petersburg Opportunities". Paper Presented at a Conference on "The World Dimension of Russia's Energy Security, 21 April 2006, at

http://www.g8.utoronto.ca/scholar/kirton2006/kirton_energy_060623.pdf

Kluge, Janis: "Mounting Pressure on Russia's Government Budget. Financial and Political Risks of Stagnation", SWP Research Paper, No. 2 (February 2019), at https://www.swpberlin.org/fileadmin/contents/products/research_papers/2019RP02_klg.pdf

Kohl, Wilfrid L.: "OPEC behavior, 1998-2001", The Quarterly Review of Economics and Finance, Vol. 42, No. 2 (June 2002), pp. 209-233.

Lajous, Adrián: “The Mexican, Saudi, and Venezuelan connection - a memoir", OIES Forum, $\mathrm{n}^{\mathrm{o}} 100$ (2015), pp. 4-11.

Lesage, Dries; Van de Graaf, Thijs and Westphal, Kirsten (2010): Global Energy Governance in a Multipolar World, Abingdon, Ashgate.

Luciani, Giacomo: "Saudi Arabia and the limits of signalling”, OIES Forum, no 100 (2015), pp. 16-19.

Lynch, Michael: "What Happened To Oil Prices In 2018?", Forbes, 2 January 2019, at https://www.forbes.com/sites/michaellynch/2019/01/02/what-happened-to-oil-prices-in2018/\#13230e296d83

Mabro, Robert: "The Oil Price Crisis of 1998”, OIES Working Paper, SP10 (1998), at https://www.oxfordenergy.org/wpcms/wp-content/uploads/2010/11/SP10-

TheOilPriceCrisisof1998-RMabro-1998.pdf.

Mann, Yossi: "Saudi Arabia's Policy Toward non-OPEC Countries", Diplomacy \& Statecraft, Vol. 23, No. 2 (2012), pp. 381-391.

Moody-Stuart, Mark: "Saudi Arabia and its role in oil markets", OIES Forum, no 100 (2015), pp. 19-22. 
Nasution, Anwar: "The Meltdown of the Indonesian Economy: Causes, Responses and Lessons", ASEAN Economic Bulletin, Vol. 17, n 2 (August 2000), pp. 148-162.

Noreng, Øystein: "Friends or fellow travellers? The relationship of non-OPEC exporters with OPEC", The Journal of Energy and Development, Vol. 4, $\mathrm{n}^{\circ} 2$ (Spring 1979), pp. 313-335.

OPEC Annual Statistical Bulletin 2000, at https://www.opec.org/opec_web/static_files_project/media/downloads/publications/ASB2000 .pdf

OPEC: "OPEC 166th Meeting concludes", OPEC Press Release, $n^{\circ} 7$ (2014), at https://www.opec.org/opec_web/en/press_room/2938.htm.

OPEC: “OPEC 167th Meeting concludes", OPEC Press Release, nº 3 (2015), at https://www.opec.org/opec_web/en/press_room/3046.htm

OPEC: "OPEC 168th Meeting concludes", OPEC Press Release, $n^{\circ} 8$ (2015), at https://www.opec.org/opec_web/en/press_room/3193.htm

OPEC: “OPEC 171st Meeting concludes", OPEC Press Release, n ${ }^{\circ} 24$ (2016), at https://www.opec.org/opec_web/en/press_room/3912.htm

OPEC: “OPEC and non-OPEC Ministerial Meeting”, OPEC Press Release, nº 25 (2016), at https://www.opec.org/opec_web/en/press_room/3944.htm

OPEC: "The 4th OPEC and non-OPEC Ministerial Meeting concludes", OPEC Press Release, $\mathrm{n}^{\mathrm{o}} 14$ (2018), at https://www.opec.org/opec_web/en/press_room/5081.htm

OPEC: "The 5th OPEC and non-OPEC Ministerial Meeting concludes", OPEC Press Release, $\mathrm{n}^{\circ} 28$ (2018), at https://www.opec.org/opec_web/en/press_room/5279.htm

OPEC: "The 7th OPEC and non-OPEC Ministerial Meeting concludes", OPEC Press Release, n 14 (2019), at https://www.opec.org/opec_web/en/press_room/5797.htm

OPEC: "The 6th OPEC and non-OPEC Ministerial Meeting concludes", OPEC Press Release, $\mathrm{n}^{\circ} 7$ (2019), at https://www.opec.org/opec_web/en/press_room/5594.htm

OPEC: "OPEC 178th (Extraordinary) Meeting of the Conference concludes", OPEC Press Release, $\mathrm{n}^{\mathrm{o}} 3$ (2020), at https://www.opec.org/opec_web/en/press_room/5865.htm

Parra, Francisco (2004): Oil Politics: A Modern History of Petroleum, London, I.B.Tauris.

Pindyck, Robert S.: "Gains to Producers from the Cartelization of Exhaustible Resources", Review of Economics and Statistics, Vol. 60, nº 2 (April 1978), pp. 238-251.

Rachovich, David: “Middle East Oil Developments 1990”, in Ayalon, Ami (ed.) (1992): Middle East Contemporary Survey, Boulder, Westview Press, pp. 277-299.

Raustiala, Kal and Victor, David G.: "The Regime Complex for Plant Genetic Resources", International Organization, Vol. 58, nº 2 (April 2004), pp. 277-309.

Raval, Anjli and Foy, Henry: "Russia and Saudi reaffirm Opec oil supply cut pledge", Financial Times, 5 October 2017, at https://www.ft.com/content/636f384c-a9d9-11e7-ab55$27219 \mathrm{df} 83 \mathrm{c} 97$

Raval, Anjli: "Opec and Russia considering 10-20 year oil alliance”, Financial Times, 27 March 2018, at https://www.ft.com/content/6788ffe8-31de-11e8-ac48-10c6fdc22f03>.

"Russia's Rosneft discusses govt compensation for OPEC deal extension - agencies", Reuters, 4 June 2019, https://www.reuters.com/article/oil-opec-russia-sechin/update-1-russias-rosneftdiscusses-govt-compensation-for-opec-deal-extension-agencies-idUSL8N23B2FW 
Sanderink, Lisa; Kristensen, Kristian; Widerberg, Oscar and Pattberg, Philipp: "Mapping the Institutional Architecture of Global Energy Governance", IVM Institute for Environmental Studies, Report R-18/02 (2018), at

https://www.researchgate.net/publication/327011883_Mapping_the_Institutional_Architectur e_of_Global_Energy_Governance

Seddon, Max: "Russia says it can deal with pain of a Saudi oil price war", Financial Times, 9 March 2020, at https://www.ft.com/content/4009472c-620e-11ea-b3f3-fe4680ea68b5

Segal, Paul: "Why Do Oil Price Shocks No Longer Shock?", OIES Working Paper, WPM 35 (2007), at https://ora.ox.ac.uk/objects/uuid:ca9ccad3-2814-4f57-8a80-

6a21367db214/download_file?file_format=pdf\&safe_filename $=$ Why $\% 2 B d o \% 2 B o i l \% 2 B$ price \%2Bshocks\%2Bno\%2Blonger\%2Bshock.pdf\&type_of_work=Working+paper.

Seymour, Ian (1980): OPEC. Instrument of Change, Basingstoke, Palgrave Macmillan.

Shwadran, Benjamin: "Middle East Oil Developments 1983-84", in Shaked, Haim and Dishon, Daniel (eds.) (1986): Middle East Contemporary Survey, Boulder - San Francisco - London, Westview Press, pp. 265-279.

Shwadran, Benjamin: "Middle East Oil Developments", in Rabinovich, Itamar and Shaked, Haim (eds.) (1987): Middle East Contemporary Survey, Boulder - San Francisco - London, Westview Press, pp. 275-297.

Shwadran, Benjamin: "Middle East Oil Developments 1988", in Ayalon, Ami and Shaked, Haim (eds.) (1988): Middle East Contemporary Survey, Boulder - San Francisco - London, Westview Press, pp. 309-332.

Smith, James L.: "Inscrutable OPEC? Behavioral Tests of the Cartel Hypothesis", The Energy Journal, Vol. 26, no 1 (2005), pp. 51-83.

Soligo, Ronald and Jaffe, Amy Myers (2004): "Market structure in the new gas economy: Is cartelization possible?", Program on Energy and Sustainable Development at Stanford University/James A. Baker III Institute for Public Policy of Rice University, (2004), at https://www.bakerinstitute.org/media/files/Research/2d926cee/GAS_IsCartelizationPossible_ 12_2004.pdf.

Sommer, Martin; Treviño, Juan and Hickey, Neil: "Oil Exporters Learn to Live with Cheaper Oil", IMF, 8 June 2016, at https://blogs.imf.org/2016/06/08/oil-exporters-learn-to-live-withcheaper-oil/\#more-13038

Sovacool, Benjamin K. and Florini Ann: "Examining the complications of global energy governance", Journal of Energy \& Natural Resources Law, Vol. 30, nº 3 (2012), 235-263.

Statista (2019): "Production cost breakdown of one barrel of oil in the top oil producing nations", Statista Research Department, at https://www.statista.com/statistics/597669/costbreakdown-of-producing-one-barrel-of-oil-in-the-worlds-leading-oil-producing-countries/

Stevens, Paul: "Resource impact: Curse or blessing? A literature survey", Journal of Energy Literature, Vol. 9, nº 1 (June 2003), pp. 3-42.

Tully, Andy: "Oil Minister Says Saudi Will Never Cut Production Regardless Of Price", Oilprice, 23 December 2014, at https://oilprice.com/Latest-Energy-News/World-News/OilMinister-Says-Saudi-Will-Never-Cut-Production-Regardless-Of-Price.html

Van de Graaf, Thijs (2013): The Politics and Institutions of Global Energy Governance, Basingstoke, Palgrave Macmillan. 
Van de Graaf, Thijs: "Organizational Interactions in Global Energy Governance", in Biermann, Rafael and Koops, Joachim A. (eds.) (2016): Palgrave Handbook of Inter-Organizational Relations, Houndmills, Palgrave Macmillan, pp. 591-609.

Van de Graaf, Thijs and Colgan, Jeff: "Global energy governance: A review and research agenda", Palgrave Communications, $\mathrm{n}^{\mathrm{o}} 2$ (January 2016), pp. 1-12.

Van de Graaf, Thijs and Zelli, Fariborz: “Actors, Institutions and Frames in Global Energy Politics", in Van de Graaf, Thijs; Sovacool, Benjamin K.; Ghosh, Arunabha; Kern, Florian and Klare, Michael T. (eds.) (2016): The Palgrave Handbook of the International Political Economy of Energy, Basingstoke, Palgrave Macmillan, pp. 47-71.

Waltz, Kenneth N. (1979): Theory of international politics, Long Grove, Waveland.

Westphal, Kirsten: "Energy Policy between Multilateral Governance and Geopolitics: Whither Europe?", IPG, nº 4 (January 2006), pp. 44-62.

Wilson, Jeffrey D.: "Multilateral Organizations and the Limits to International Energy Cooperation", New Political Economy, Vol. 20, nº 1 (2015), pp. 85-106.

Wingfield, Brian; Dodge, Samuel and Sam, Cedric: "OPEC and Allies Part Ways on Oil Cuts", Bloomberg, 15 August 2018, at https://www.bloomberg.com/graphics/opec-production-targets/

World Bank (2017): "Oil rents (\% of GDP)", World Bank Data, at https://data.worldbank.org/indicator/NY.GDP.PETR.RT.ZS?end=2017\&most_recent_value_d esc $=$ true $\&$ start $=2000$

World Bank (2015): "Special Focus. Anatomy of the last four oil price crash", Commodity Markets Outlook. 